Relations industrielles

Industrial Relations

\title{
Recommandations internationales sur les statistiques du
} travail, par Bureau international du travail, Genève, 1975, 139

p.

\section{Gérard Dion}

Volume 30, numéro 4, 1975

URI : https://id.erudit.org/iderudit/028670ar

DOI : https://doi.org/10.7202/028670ar

Aller au sommaire du numéro

Éditeur(s)

Département des relations industrielles de l'Université Laval

ISSN

0034-379X (imprimé)

1703-8138 (numérique)

Découvrir la revue

Citer ce compte rendu

Dion, G. (1975). Compte rendu de [Recommandations internationales sur les statistiques du travail, par Bureau international du travail, Genève, 1975, 139 p.] Relations industrielles / Industrial Relations, 30(4), 801-802.

https://doi.org/10.7202/028670ar

Tous droits réservés @ C Département des relations industrielles de l'Universite Laval, 1975
Ce document est protégé par la loi sur le droit d'auteur. L’utilisation des services d’Érudit (y compris la reproduction) est assujettie à sa politique d'utilisation que vous pouvez consulter en ligne.

https://apropos.erudit.org/fr/usagers/politique-dutilisation/ 
Critères de fixation du quantum; 400-05- Entente entre les parties; 400-06- Indemnité transmissible aux héritiers; 400-07-Cas de rappel au travail. Enfin, les sous-catégories sont elles-mêmes le plus souvent subdivisées en thèmes particuliers d'étude. A titre d'illustration, la sous-catégorie 100-01Notion de congédiement de la catégorie 100- Généralités présente les décisions en fonction des thèmes suivants: 100-11- Notion de suspension; 100-21Notion de lock-out; 100-31- Notion de mise à pied; 100-41- Notion de déplacement; 100-51- Notion de démission. Il suffira à l'utilisateur du Répertoire de quelques exercices pour découvrir les nombreux avantages de la méthode de codification utilisée par le professeur Descôteaux. Elle permet notamment, par un jeu de renvoi reposant sur le no. de codification, de signaler l'existence d'une même décision dans différents thèmes où ladite décision peut avoir une importance.

Les espèces jurisprudentielles répertoriées entre janvier 1962 et fin 1973 sont le résultat d'une analyse exhaustive. Le fait que Me Descôteaux ait procédé par l'étude des dossiers des différents organismes en est la garantie. Ces espèces sont présentées sous forme de sommaires. La démarche de rédaction est en principe la suivante: un bref rappel des faits; une mise en relief de l'objet du litige; la décision suivie de ses motifs; dégagement du principe résultant de la décision. Les utilisateurs du premier tome remarqueront que la démarche n'a pas subi de modification. On doit signaler que quelques-unes des espèces rapportées ne constituent plus de nos jours des guides, comme par exemple la fameuse affaire Bergeron (p. 21 du Répertoire); l'auteur a d'ailleurs invité le lecteur dans l'avant-propos à utiliser le volume en tenant compte des effets de l'écoulement du temps et, de plus, signalé généralement les décisions récentes infirmant celles de la période 1962-69 ou proposant une nouvelle orientation.

Les décisions et jugements rendus entre la période 1969 et fin 1973 ont été regroupés et classifiés selon le plan général de l'ouvrage. Ces décisions sont citées selon les besoins après les espèces résumées dans le cadre des sous-catégories ou thèmes. On ne présente cependant aucune idée du contenu de ces décisions. A la décharge de l'auteur, nous signalons que le rappel des cas jurisprudentiels récents n'est qu'un complément au Répertoire. Ce complément apparaît comme le premier essai visant à regrouper sous des thèmes précis les jugements rendus en application des articles 14 et ss. du C. du t.

Ce second tome du Répertoire nous apparaît comme une oeuvre colossale de synthèse des décisions des anciens organismes chargés de voir à l'application et à l'interprétation du Code du travail. Il s'agit d'une oeuvre importante qui ne peut échapper à l'attention de ceux qui s'intéressent aux problèmes soulevés par le congédiement pour activités syndicales. Nous espérons que cet ouvrage sera utilisé dans la recherche fondamentale et qu'il sera suivi de mises-à-jour périodiques.

\section{Rodrigue BLOUIN}

Université Laval

\section{Recommandations internationales sur les statistiques du travail par Bureau in- ternational du travail, Genève, 1975, $139 \mathrm{p}$.}

On sait que depuis sa création, l'Organisation internationale du travail a joué un rôle considérable pour normaliser les statistiques du travail. Le BIT a organisé une série de conférences internationales des statisticiens du travail; les résultats des travaux, d'abord présentés sous forme de résolutions pour approbation par le Conseil d'administration du BIT, ont par la suite été adoptés comme des recommandations.

Depuis la publication en 1959 de La normalisation internationale des statistiques du travail, trois Conférences internationales ont été tenues. Cet ouvrage vient présenter d'une façon systématique les principales recommandations actuellement en vigueur.

Il est divisé en dix chapitres: principales classifications économiques; maind'oeuvre, emploi, chômage et sous-emploi; salaire, durée du travail, coût de la main-d'oeuvre et revenu salarial; indices des prix à la consommation; enquêtes sur les conditions de la vie des familles; comparaisons internationales des salaires réels; sécurité sociale; lésicns professionnelles; conflits du travail; conventions collectives. Un annexe ccmprend la liste des Conférences internationales avec les questions qui $\mathrm{y}$ ont été examinées. 
Chaque chapitre est conçu selon le même plan. Après une brève introduction retraçant l'oeuvre accomplie par l'OIT ou d'autres organismes internationaux ainsi que le travail des Conférences internationales ou des réunions d'experts, on donne une bibliographie des ouvrages à consulter. Ensuite, comme documents, sont publiés les textes mêmes des recommandations qui ont été adoptées.

En raison de l'autorité et du prestige dont jouit le BIT, il est inutile de souligner l'importance d'un pareil ouvrage et son utilité pour tous ceux qui s'occupent des relations professionnelles.

\section{Gérard DION}

Université Laval

Consult and Advise: A History of the
National Joint Council of the Public
Service of Canada 1944-1974, by L.W.C.S. Barnes, Kingston, Industrial Relations Centre, Queen's University, 1975, 203p.

Staff relations in the federal public sector, since 1967 , has centred primarily on the adversary approach to the resolution of disputes through the operation of collective bargaining. However, within the industrial relations system, a mechanism for union-management consultation has been established for discussion and resolution of a wide variety of subject matters of mutual interest and concern to employees and the employer. The National Joint Council of the Public Service of Canada, more commonly referred to as the NJC, is the mechanism and its establishment and operation pre-date the collective bargaining era by some twenty-three years. The author of this volume was, for many years, a representative of the Staff Side of the NJC and, accordingly, the foundations for his study are based on first-hand experience in the evolution and operation of the Council. In large part, this is a study of a mechanism which has had a significant impact on employer-employee relations in the Public Service of Canada, both prior and subsequent to the advent of collective bargaining.

The volume has eleven chapters and two appendicies which divide into four maior periods. The first and second periods are concerned with the years prior to the establishment of and the early workings of the NJC; the third is an account of the fruitful period in the 1950's and early 1960's; and the fourth segment examines the workings of the Council since the inception of collective bargaining. In addition, the author provides the reader with two detailed examples of the success of consultation in resolving two very thorny problems which faced the Public Service in the early 1970's. In his concluding chapter, the author has consulted his crystal ball to speculate on the Council's future.

The Civil Service National Whitley Council in Great Britain, established in 1919, was the first attempt at providing machinery for employer-employee consultation. The success of this system inspired the Canadian Civil Service staff organizations to urge successive governments to establish a similar mechanism in Canada. In 1928 the House of Commons endorsed the recommendation of a select committee on industrial relaticns that the Government form a committee to draft a constitution for a Council. Despite this, it was not until 1930 that an Order in Council was approved to establish such a committee. However, an election and change of government prevented its establishement. A further fourteen years elapsed before the staff associations were sufficiently strong and unified and the government was committed to a policy of employee representation and industrial relations in private industry for any further developments to take place. In February 1944, the Government indicated its acceptance of the principle of consultation and by Order-in-Council PC 3676 of May 16, 1944, the National Joint Council was established.

The first two and a half years of the Council's existence were bereft of any significant accomplishments. In the twilight years of the 1940's, statutory holidays, liquidation of overtime, conditions of retirement, hours of work, working conditions, permanent appointment of employees, cafetaria facilities, automobile insurance, group medical insurance, and efficiency rating forms provided the Council with its regular agenda items. Progress on these items was often interrupted by unexpected events such as amendments to legislation affecting public servants or problems concerning the day to day operation of the service being placed before the 